\title{
Shame and self-esteem in androgenic alopecia patients
}

\section{Poczucie wstydu i samoocena u pacjentów z łysieniem androgenowym}

\author{
Joanna Furmańska', Ryszard W. Żaba², Teresa N. Rzepa ${ }^{3}$, Przemysław Kubaszewski ${ }^{4}$
}

'Department of Psychology, University of Szczecin, Szczecin, Poland

2Department of Dermatology and Venereology, Poznan University of Medical Sciences, Poznan, Poland

${ }^{3}$ Psychotherapy Centre SensTerapia, Poznan, Poland

${ }^{4}$ University of Social Sciences and Humanities, Poznan Campus, Poznan, Poland

'Instytut Psychologii, Uniwersytet Szczeciński, Szczecin, Polska

2Zakład Dermatologii i Wenerologii, Uniwersytet Medyczny im. Karola Marcinkowskiego, Poznań, Polska

${ }^{3}$ Ośrodek Psychoterapii SensTerapia, Poznań, Polska

${ }^{4}$ SWPS Uniwersytet Humanistycznospołeczny, Wydział Zamiejscowy w Poznaniu, Poznań, Polska

Dermatol Rev/Przegl Dermatol 2021, 108, 314-316

DOI: https://doi.org//0.5 I |4/dr.2021.1 10736

Quality of hair has long been a major element of self-image, influencing one's convictions regarding beauty and physical attractiveness. Even the smallest disorders in this area have a negative effect on people's well-being and general mood, which in turn contributes to a decreased self-esteem and quality of life. This is accompanied by unpleasant emotions such as embarrassment, shame, anxiety, apprehension and fear of being scrutinised by other people, and in a long-term perspective - phobias, psychosomatic diseases, as well as depressive, alexithymic, and obsessive-compulsive disorders [1-3].

We decided to assess shame and self-esteem as well as identify relationships between these two in men suffering from androgenic alopecia.

The study was performed in two stages. First, in consultation with physicians, a list of 35 most shameful diseases was compiled. Following an initial research study involving 314 persons, a short list of 10 diseases was established, which were subsequently assessed by 219 persons by means of a scale ranging from 1 to 10 (from the lowest to the highest level of shame) [4]. The second stage of the study additionally involved 39 androgenic alopecia men aged from 19 to $66(\mathrm{M}=35.8)$. The male patients filled in the originally developed survey comprising 6 half-open questions based on the several-year medical and psychotherapeutic experience of the research team. Moreover, the patients filled in the Rosenberg Self-Esteem Scale (SES) [5]. The study was approved by the Committee for Bioethics of the Poznan University of Medical Sciences (200/16).
Wygląd włosów jest uważany za istotny element, który wpływa na postrzeganie własnego wizerunku i stopnia atrakcyjności fizycznej. Zaburzenia dotyczące włosów mają niekorzystny wpływ na samopoczucie i ogólny nastrój, co przyczynia się do obniżenia samooceny i jakości życia. Towarzyszą temu nieprzyjemne emocje, m.in. uczucie zażenowania i wstydu, niepokój, lęk i obawa przed oceną innych ludzi, a w dalszej perspektywie również fobie, choroby psychosomatyczne oraz zaburzenia depresyjne, aleksytymiczne i obsesyjno-kompulsywne [1-3].

W związku z tym postanowiliśmy przeprowadzić analizę uczucia wstydu i poczucia własnej wartości, a także określić zależności między tymi czynnikami u mężczyzn z łysieniem androgenowym.

Badanie przeprowadzono w dwóch etapach. W pierwszej kolejności w porozumieniu z lekarzami przygotowano wykaz 35 chorób uważanych za najczęściej powodujące uczucie wstydu u pacjentów. We wstępnym badaniu z udziałem 314 osób zdrowych i chorych ustalono krótką listę 10 chorób wywołujących poczucie wstydu, które następnie poddano ocenie przy zastosowaniu skali od 1 do 10 (od najniższego do najwyższego poziomu wstydu) w grupie 219 osób [4]. W drugiej fazie do badania włączono 39 mężczyzn z łysieniem androgenowym w wieku od 19 do 66 lat (średnia wieku: 35,8 roku), którzy wypełnili autorski kwestionariusz ankiety złożony z 6 pytań półotwartych. Pytania ankietowe opracowano na podstawie wieloletniego doświadczenia medycznego i psychoterapeutycznego członków zespołu badawczego. Oprócz tego pacjenci wypełnili kwestionariusz ogólnego badania poziomu 


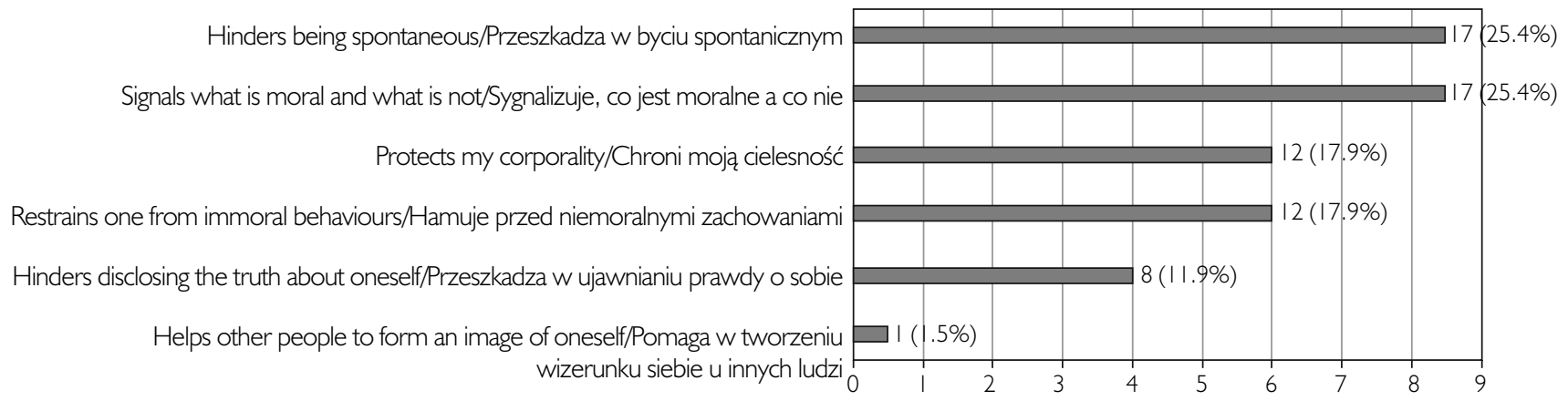

Figure I. List of the shame functions according to androgenic alopecia patients

Rycina I. Funkcje wstydu według pacjentów z łysieniem androgenowym

Results show that out of the 10 short-listed diseases, the most shameful one, according to the androgenic alopecia patients, is AIDS with the result of 7.9 points (79\%). After that, in reference to AIDS as the most (in $100 \%$ ) shameful disease, they evaluated the level of shamefulness of their own disease to be $32 \%$ on average $(\mathrm{SD}=30)$. The patients have stated that shame mainly serves the function of signalling what is moral and what is not, and of hindering own spontaneity (25.4\% responses each) (fig. 1 ). It was found that there is no statistically relevant correlation $(p>0.05)$ between the level of shame experienced because of one's illness and the functions assigned to the emotion of shame. However, a statistically relevant negative correlation $(p<0.05)$ was found between the self-esteem level and two functions of shame, i.e. hindering the disclosure of truth about oneself $(r=-0.377)$ and hindering the spontaneity $(r=-0.317)$. The observations demonstrate that apart from the merely biological course of the disease, its psychosocial consequences are to be evaluated and monitored. Conclusions drawn from this research study should be treated as important first and foremost for dermatologists, psychologists and psychotherapists. They should take into account the inhibiting and defensive function of shame, which may seriously modify androgenic alopecia patients' behaviours in direct interactions and disrupt their participation in the treatment process $[6,7]$.

\section{CONFLICT OF INTEREST}

The authors declare no conflict of interest. samooceny według Skali samooceny Rosenberga (SES) [5]. Przed przeprowadzeniem badania uzyskano zgodę Komisji Bioetycznej Uniwersytetu Medycznego im. Karola Marcinkowskiego w Poznaniu (nr 200/16).

Wyniki wskazują, że zdaniem pacjentów z łysieniem androgenowym chorobą powodującą u nich największy wstyd spośród 10 chorób umieszczonych na krótkiej liście jest AIDS z wynikiem 7,9 pkt (79\%). W kolejnym etapie badania uczestnicy ocenili poczucie wstydu towarzyszące własnej chorobie w odniesieniu do AIDS (100\%). Uzyskano średni wynik 32\% (SD = 30). Zdaniem pacjentów główna funkcja wstydu polega na sygnalizowaniu, co jest moralne, a co nie, oraz hamowaniu spontaniczności (25,4\% odpowiedzi dla każdej z opcji) (ryc. 1). Wykazano brak statystycznie istotnej zależności $(p>0,05)$ między poziomem wstydu odczuwanego z powodu choroby i funkcjami przypisywanymi emocji wstydu. Stwierdzono natomiast istotną statystycznie ujemną zależność $(p<0,05)$ między poziomem samooceny i dwiema funkcjami wstydu, tj. utrudnianiem ujawniania prawdy o sobie $(r=-0,377)$ oraz hamowaniem spontaniczności $(r=-0,317)$. Obserwacje wskazują, że poza biologicznym przebiegiem choroby należy także poddawać ocenie i monitorować skutki psychospołeczne. Wnioski z przeprowadzonego badania są szczególnie przydatne dla dermatologów, psychologów oraz psychoterapeutów. Powinni oni uwzględniać hamującą i obronną funkcję wstydu, która może poważnie oddziaływać na zachowania osób z łysieniem androgenowym w bezpośrednich interakcjach, a także niekorzystnie wpływać na ich zaangażowanie $w$ proces leczenia $[6,7]$.

\section{KONFLIKT INTERESÓW}

Autorzy nie zgłaszają konfliktu interesów. 


\section{References}

\section{Piśmiennictwo}

1. Cash T.F.: The psychological consequences of androgenetic alopecia: a review of the research literature. Br J Dermatol 1999, 141, 398-405.

2. Gupta S., Goyal I., Mahendra A.: Quality of life assessment in patients with androgenetic alopecia. Int J Trichology 2019, 11, 147-152.

3. Picardi A., Pasquini P., Cattaruzza M.S., Gaetano P., Baliva G., Melchi C.F., et al.: Psychosomatic factors in first-onset alopecia areata. Psychosomatics 2003, 44, 374-381.

4. Rzepa T., Jakubowicz O., Witmanowski H., Żaba R.: Disease-induced level of shame in patients with acne, psoriasis and syphilis. Adv Dermatol Allergol 2013, 30, 233-236.

5. Dzwonkowska I., Lachowicz-Tabaczek K., Laguna M.: Samoocena i jej pomiar. SES. Pracownia Testów Psychologicznych, Warszawa 2008.

6. Tangney J.P., Dearing R.L.: Shame and Guilt (Emotions and Social Behavior). Guilford Press, New York 2002.

7. Hasson-Ohayon I., Ehrlich-Ben Or S., Vahab K., Amiaz R., Weiser M., Roe D.: Insight into mental illness and self-stigma: the mediating role of shame proneness. Psychiatry Research 2012, 200, 802-806.

Received: 8.09.2020

Accepted: 17.05 .2021

Otrzymano: 8.09.2020 r.

Zaakceptowano: $17.05 .2021 \mathrm{r}$. 